\section{俩 Heighten Science \\ P U B L I C I T I O N S Corporation ISSN \\ 2576-9510}

\title{
Livestock insurance a tool to reduce economical loss of farmers from climate change related Hazards
}

\author{
Ananta Koirala ${ }^{1 *}$ and Priyanka Bhandari² \\ 'Veterinary Doctor, Government of Nepal, Nepal \\ ${ }^{2}$ Himalayan college of Agricultural sciences and technology, Nepal
}

*Address for Correspondence: Dr. Ananta Koirala, Veterinary Doctor, Government of Nepal, Nepal, Email: koiralaananta24@gmail.com

Submitted: 02 July 2018

Approved: 20 July 2018

Published: 23 July 2018

Copyright: @ 2018 Koirala A, et al. This is an open access article distributed under the Creative Commons Attribution License, which permits unrestricted use, distribution, and reproduction in any medium, provided the original work is properly cited.

Keywords: Climate change; Insurance; Livestock holders; Climatic hazards

\section{Abstract}

Climate change brings extreme events like drought, landslide, flood and anticipated more constraint to profitable livestock production causing huge economical loss in the livestock sector of the country. Deaths of livestock and damage to farms and farm infrastructure is causing a huge loss, small livestock holders are highly venerable to such climatic hazards. So to cope with these uncertain climatic hazards livestock insurance is the one of the best strategies. This study reveals that different climatic hazards is been experienced by the livestock holders of Kaski, Dolakha and Jhapa district of Nepal, $62 \%$ of the respondent has observed the change in climate. Of the total respondents perceived around $47 \%$ farmer have insured their livestock in Kaski district, 33\% in Jhapa and $20 \%$ in Dolakha district. Beside the proper vaccination, deworming, management and feeding of animals people are insuring their livestock assets due to uncertain in the climatic pattern and its consequences, this shows that livestock insurance is the one of the tool to mitigate with changing climate and climate relate hazard in livestock sector of Nepal.

\section{Introduction}

Global warming is an issue of the today's world. It is affect in the agriculture, livestock, environment and natural resources of the developing country. Due to the changing temperature there is increase in the maximum temperature in Nepal. From the year 1977 and 1999 temperature has increased by $0.9^{\circ} \mathrm{C}$, at a rate of $0.03^{\circ} \mathrm{C}$ to $0.12^{\circ} \mathrm{C}$ per year, whereas the global average surface temperature rise of the last century was $0.6 \pm 0.2^{\circ} \mathrm{C}[1]$ and the global average surface temperature rose to $0.85{ }^{\circ} \mathrm{C}$ till 2012 (IPCC,2014). Nepal has a very diverse and fragile topography; it is the $20^{\text {th }}$ topmost disaster prone country in the world. It is ranked on $4^{\text {th }}$ place with regard to vulnerability to climate change, and $30^{\text {th }}$ for flood related calmatives as reported by Ministry of Home Affairs [2]. Nepal faces high magnitudes and intensities of a multiple natural hazards such as flood, landslide, fire, hailstone, windstorm, thunderbolt, cloudburst, drought, glacier lake outburst flood, avalanches and epidemics each year resulting to huge loss of human, livestock, agriculture and infrastructure.

Livestock rearing is a major source of income, food and nutrition, manure for the farmers of Nepal. As Nepal is venerable to climate change, impact of climate change is seen in the agriculture, livestock, forest and natural resources of the country. Climate change brings extreme events like landslide, flood and drought in the country. It causes losses of lives of people and livestock, damage to the agriculture, forest and infrastructure. Studies on livestock and climate change revealed that climate change adversely affects the animal health and livestock production. An increase in extreme climate events, such as droughts and floods, it anticipates more constraint to profitable livestock production [3]. Every year farmers have large economical loss due to losing the livestock due to such climatic hazards. In the year 2013 (1,535 animals) were

How to cite this article: Koirala A, Bhandari P. Livestock insurance a tool to reduce economical loss of farmers from climate change related Hazards. Insights Vet Sci. 2018; 2: 005-008. https://doi.org/10.29328/journal.ivs.1001008 
killed by climatic hazards. Fire killed 613, thunderbolt killed 547, landslide killed 148, flood killed 131, heavy rainfall killed 66 and avalanche killed 30 animals. Similarly in the year 2014 large number of animals (5282) was killed, maximum numbers of animals were killed by flood disaster. Flood alone killed 4,437 (84 \%) animals of the total animals killed in the year 2014. Fire killed 697 (13\%) animals; Landslide killed $69(1 \%)$ animals [2].

An initial report prepared by the Ministry of Livestock Development (MoLD), on the recent flood in the August, 2017 in terai of Nepal the livestock sector has incurred a loss of around Rs. 1 Billion due to deaths of livestock and damage to farms and other infrastructure. Above 140,000 livestock, including cows, buffaloes, goats, chickens and pigs were killed in the floods and landslides triggered by heavy rainfall. The floods killed 133,854 chickens worth Rs. 107 million, 119 cows and 3,032 oxen worth Rs. 11.9 million in total, 53 buffaloes worth Rs.5.3 million, 1,970 goats worth Rs. 44.5 million and 755 pigs worth Rs. 22.6 million were killed in the floods. The floods damaged and swept away the livestock industries and poultry farms worth Rs. 300 million. Animal feeds worth Rs. 500 million were destroyed. This uncertainty in the weather and weather related hazards is causing huge economical loss to the livestock farmers so livestock insurance is the best way to reduce the economic loss of the livestock holders.

Nepal government has started an insurance policy in the livestock and poultry from June 2013. The subsidy was 50\% initially and was raised to 75\% in August 2014 to attract the farmers for insuring livestock and poultry. Insurance covers species of animals like cows, ox, buffalos, yak, Nak, sheep, goat, swine, chicken and ducks. Maximum sum insured for high-breed dairy cow and buffalo are Rs 150,000 and Rs 125,000 , respectively. Similarly, sum insured for water buffalo and ox raised for reproductive purpose has been fixed at Rs 70,000, while insurance coverage for water buffalo's and oxen used for transportation purpose has been fixed Rs 40,000. Likewise sheep and goat raised for meat production cannot exceed Rs 8,000, while maximum insurance coverage for different types of chicken and duck have been fixed at Rs 1,200 and Rs 700, respectively. For animals the premium payable is $5 \%$ of the sum assured. All risks are covered; in case of animals, $90 \%$ of the sum assured is paid in death and $50 \%$ for permanent total disability. For commercial birds the premium payable is $6 \%$ and for domestic birds it is 5\%. Risks covered are fire, lightning, flood, inundation, landslide, storm, hailstorm, snow, frost, illness and diseases. (Ministry of Agricultural Development, 2014)

\section{Materials and Methods}

\section{Study site, sampling, data collection}

The study place includes three districts of Nepal. Jhapa from Terai region, Dolakha from the Mountain region and Kaski from the Hilly region of Nepal. These Districts were selected purposively as livestock rearing is major source of income for the livelihood of the people living in these districts. From each district 100 households were selected using purposive simple random sampling technique. A total of 300 households were used for the survey. The primary data was collected through household survey using pretested semi structured questionnaire via face to face interview during July 2016 to February 2017. The questionnaire survey focused on perception of the climate change, major effect on livestock due to changing climate and possible adaptation measures, knowledge about the various livestock insurance policies, constrains of insurance and livestock insurance a way to mitigate with changing climate were assessed.

\section{Data management and analysis}

All quantitative data were entered in the Statistical Package for Social Science (SPSS 16 version). Microsoft Word, Microsoft Excel, and SPSS were used for data processing, analysis, and interpretation of information. 


\section{Results}

\section{Perception of the respondents on experience of climate change}

A perception of the change in climate was done by questioner survey. Change in the temperature, rainfall pattern, intensity of the rainfall, drought, flood, pest infection and hailstone are the major climate change issue people have noticed. $62 \%$ of the respondent has observed the change in climate.

\section{Ranking of various hazards affecting the large and small ruminants}

Similarly, study revealed that disease and pest infection, drought, flood and hailstone are the major factors affecting the large and small ruminants in these districts. The occurrences of these calamities are seen more in the mountain and hill. Nearly $68.0 \%$ of total respondents perceived increase in temperature, increase in rainfall intensity, and increase in climatic calamities like flood, landslide, hailstone, disease and pest as compared to last five years (Figures 1,2).

\section{Animal insurance in the study area}

The knowledge of animal insurance by the farmers was observed in the questioner survey. Of the total respondents perceived around $47 \%$ farmer have insured their livestock in Kaski district, 33\% in Jhapa and $20 \%$ in Dolakha district. Beside the proper vaccination, deworming, management and feeding of animals people are insuring their livestock assets due to uncertain in the climatic pattern and its consequences. As 62 $\%$ of the people have observed the change in climatic and has adopted insuring the livestock as major mitigation strategies for the climatic hazards.

Still all the livestock holders has not gone for the insurance of the livestock due to lack of awareness, unwillingness of the farmers due to complex process of insurance, inadequate approaches of the insurance company in their area and delay in the claim payment procedure by the insurance company.
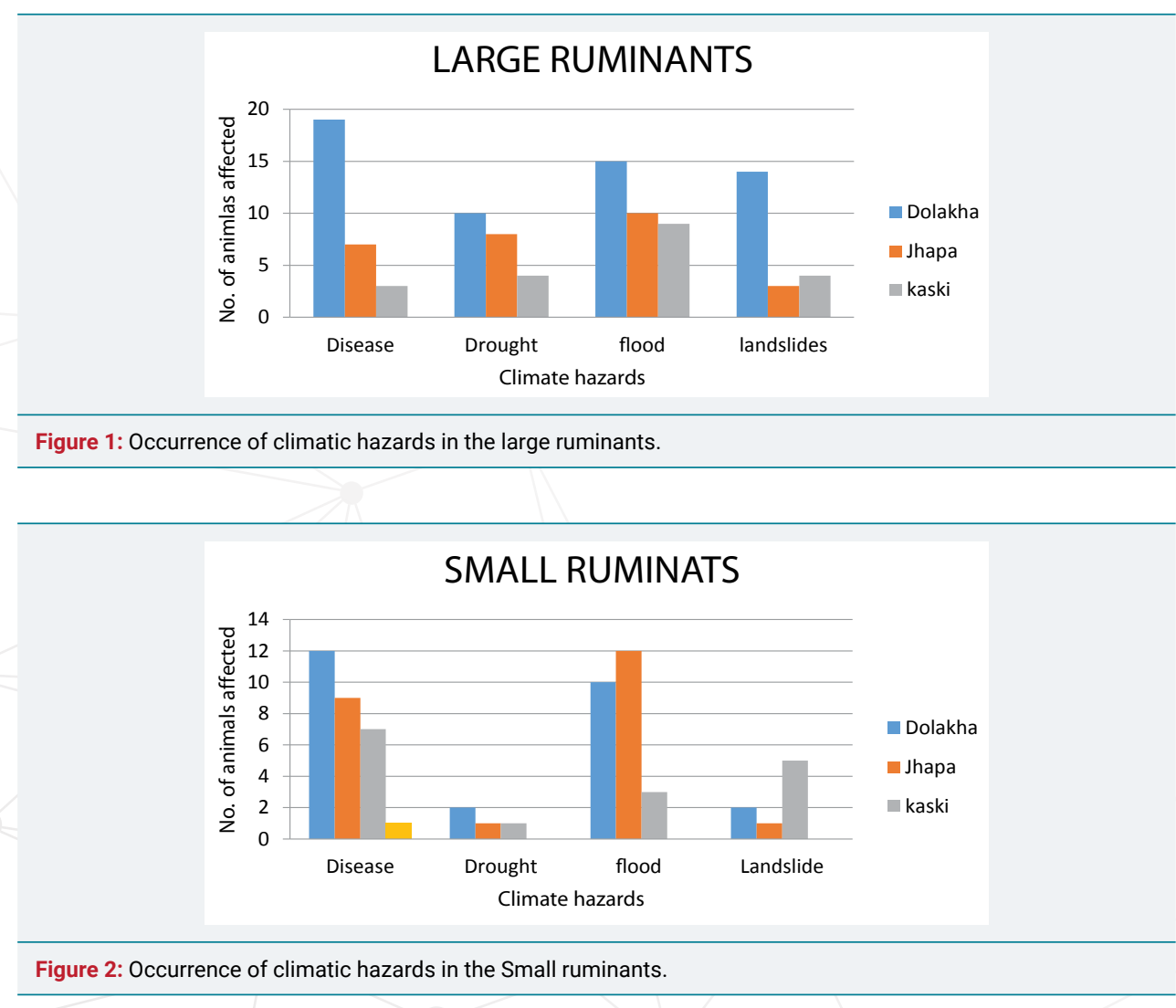


\section{Conclusion}

Climate change brings extreme events like drought, landslide, flood and anticipated more constraint to profitable livestock production causing huge economical loss in the livestock sector of the country. Deaths of livestock and damage to farms and farm infrastructure is causing the farmers a huge loss, small livestock holders are highly venerable to such climatic hazards. So cope with these uncertain climatic hazards livestock insurance is the one of the best strategies. All though lack of knowledge of livestock insurance, lack of the interest of the insurance company to work in the remote area is also the major constrains. Most of livestock holders of the three districts had observed the variation on weather and climatic patterns and experienced increased temperature, increase in the intensity and frequency of the rain. Landslide, floods, drought, increase in disease were major hazards and extremities of the climate. Livestock holders have started to mitigate with the changing climate and have adopted insurance as the one of the major tool to mitigate with the climatic hazards to protect the livestock assets.

Combining data of climate and weather, livestock supply, and insurance market (institutional) a multidimensional perspective can be developed for various regions and formulate a well suited livestock index insurance by the government to prevent the economical loss of the livestock holders and Government policies should indorse the insurance company to give service to the livestock holders in remote villages.

\section{References}

1. Shrestha AB, Wake CP, Mayewski PA, Dibb JE. Maximum Temperature Trends in the Himalaya and Its Vicinity: An Analysis Based on Temperature Records from Nepal for the Period 1971-94. In J Climate. 1999; 12: 2775-2787. Ref.: https://tinyurl.com/y8tho8sy

2. MOHA. Nepal Disaster report, Ministry of Home Affairs and Disaster Preparedness Network-Nepal (DPNet-Nepal). 2015.

3. Christensen L, Coughenour MB, Ellis JE, Chen ZZ. Vulnerability of the Asian typical steppe to grazing and climate change. Climate Change. 2004; 63: 351-368. Ref.: https://tinyurl.com/y79fcjsp

4. IPCC. Climate Change 2014 Synthesis Report Summary for Policymakers. 2014.

5. MOAD. Agriculture and livestock insurance policy, Ministry of Agricultural Development. 2013

6. MOAD. Agriculture and livestock insurance premium subsidy policy, Ministry of Agricultural Development. 2014.

7. MOLD. Report on the livestock death due to recent flood in Terai, Ministry of Livestock Development. 2017.

8. MOHA. Nepal Disaster Report, 2015, Ministry of Home Affairs, Kathmandu. 2009.

9. MOHA. Draft of Disaster Management Bill 2010, Ministry of Home Affairs, Kathmandu MOF, 2010: Economic Survey 2066-67, Ministry of Finance, Kathmandu. 2010.

10. MOHA. Disaster Scenario in Nepal (Unpublished data), Disaster Management section, Ministry of Home Affairs, Kathmandu. 2010. 